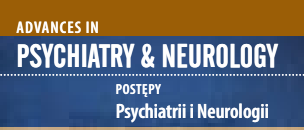

Correspondence to/Adres do korespondencji:

Wiktor Orlof

Department of Psychiatry

Medical University of Bialystok (UMB)

pl. Brodowicza 1

16-070 Choroszcz, Poland

e-mail:w_orlof@wp.pl

Submitted/Otrzymano: 19.04.2021

Accepted/Przyjęto do druku: 27.06.2021

\section{Dissociative identity (multiple personality) disorder in Poland: a clinical case description and diagnostic difficulties} Dysocjacyjne zaburzenie tożsamości (osobowość mnoga) w Polsce opis przypadku klinicznego i trudności diagnostyczne

\author{
Wiktor Orlof ${ }^{(1 D}$, Emil B. Rozenek², Napoleon Waszkiewicz' (D), \\ Bogumiła Szewczak ${ }^{3}$
}

'Department of Psychiatry, Medical University of Bialystok (UMB), Bialystok, Poland IIndependent Public Complex of Healthcare Institutions in Wyszków, Poland ${ }^{3}$ The Medical University Clinical Hospital in Bialystok, Poland

\begin{abstract}
Purpose: Dissociative identity disorder (DID) is characterized by the presence of a minimum of two identities. Each identity has different fixed patterns of perception, establishing relationships, and thinking about itself and the environment in which it lives. The etiology of dissociative identity disorder is still not fully understood. The aim of the study is to review the literature on the psychopathology and diagnostics of DID and to describe the clinical case of a patient with co-existing DID and paranoid schizophrenia. Case description: The male patient discussed in the article is characterized by the presence of three separate identities (the dominant male personality, and two additional personalities, male and female). The main personality informing about the existence of the others is the female personality, with a female name.

Comment: Psychiatrists and psychologists, as well as doctors of other specialties, should have knowledge about the symptomatology of dissociative identity disorder in order to have a holistic approach to patient care.
\end{abstract}

Key words: case report, dissociation, dissociative identity disorder, multiple personality.

\title{
Streszczenie
}

Cel: Dysocjacyjne zaburzenie tożsamości (dissociative identity disorder - DID) charakteryzuje się obecnością co najmniej dwóch tożsamości. Każda tożsamość ma inne ustalone wzorce postrzegania, nawiązywania relacji, myślenia o sobie lub środowisku, w którym żyje. Etiologia DID wciąż nie została w pełni poznana. Celem pracy jest przegląd piśmiennictwa z zakresu psychopatologii i diagnostyki DID oraz opis przypadku klinicznego pacjenta ze współistnieniem DID i schizofrenii paranoidalnej.

Opis przypadku: Pacjent opisany w artykule charakteryzuje się obecnością trzech odrębnych tożsamości (główna osobowość męska oraz dwie dodatkowe osobowości - męska i żeńska). Dominującą osobowością informującą o istnieniu innych jest osobowość kobieca o żeńskim imieniu.

Komentarz: Psychiatrzy, psycholodzy, a także lekarze innych specjalności powinni mieć wiedzę na temat symptomatologii DID, aby mieć całościowe podejście do opieki nad pacjentem.

Słowa kluczowe: opis przypadku, dysocjacja, dysocjacyjne zaburzenie tożsamości, osobowość mnoga. 


\section{PURPOSE}

The aim of the study is to examine the psychopathology and diagnostics of dissociative identity disorder (DID), and to discuss a clinical case of the patient with DID and coexisting paranoid schizophrenia.

The article consists of two parts. The first is a review devoted to the phenomenon of dissociation and the definition of DID. A search was conducted in March 2021 of the Medline database, using the keywords "dissociative disorders", and "dissociative identity disorder". Only the most important and up-to-date studies were included in this review. The second part is a case-study of a patient hospitalized in the Psychiatric Clinic of the Medical University of Bialystok (Poland).

Dissociation (Latin: dissociatio) is a concept that covers a wide range of experiences that connect a sense of separation from reality. It is a kind of continuum; the mildest forms - non-pathological states of dissociation - consist of a simple separation from the immediate surroundings, e.g. daydreams, and the severe forms constitute pathologically altered states of consciousness, e.g. dissociative amnesia and identity disorder. The basis of dissociation is a disturbance of some cognitive processes (e.g. memory integration and consistency, sense of self-identity, receiving stimuli, and motor control of one's body), related to personal (usually traumatic) experiences [1]. This disturbance can be characterized by an inability to control the cognitive activities or processes that are usually subject to such control; the activities and processes themselves are essentially correct. The patient, however, "separates" himself from his memories, identity, and even from his body and surroundings. Symptoms are usually self-limiting and less likely to be chronic. DID is also part of the spectrum of dissociation disorders $[1,2]$. In the ICD-10 these are within the Dissociative [Conversion] Disorders section. All other dissociative disorders in the ICD-10 have equivalents in the DSM-5 Dissociative Disorders section [2-4].

DID is also called multiple personality disorder. It is characterized by the presence of a minimum of two identities and/or personality states. Each identity has different fixed patterns of perception, establishing relationships, and thinking about itself and the environment in which it lives $[2,4]$. Although DID was observed and described for the first time at the turn of the century, psychiatrists needed many years to better understand the psychopathology of this disorder. Many psychiatrists still doubt the existence of dissociative personality disorders, others do not recognize them, usually due to insufficient scientific data $[5,6]$. DID may be more common in society than previously thought, but many aspects of it remain unexplored.

The incidence rate of DID was determined on the basis of an analysis of environmental studies, estimated at an average of about $1 \%$ in the general population (though it is more common in the female population). In a study on women in central Turkey, the incidence of DID was $1.1 \%$, while in Winnipeg (Canada) it was estimated to be $1.3 \%$. Therefore, DID is not a rare disease: on the contrary, as it may occur with a frequency similar to that of schizophrenia [2, 7-9].

DID is particularly common in patients diagnosed with depression, post-traumatic stress disorder (PTSD), and psychoactive substance abuse. In addition, it is found to be more common in patients with psychosomatic disorders and personality disorders, particularly the borderline type $[6,7,10,11]$. Generally, the principal incidence of dissociative disorders is more common in people with a history of suicide attempts, experience of sexual harassment, and physical or emotional neglect in childhood, as well as in women after an abortion and in patients with other related to gender identification disorders $[7-9,11,12]$.

The etiology of DID is still not fully understood. In retrospective studies, the main causative role in the appearance of DID can be played by the following: traumatic life experience such as childhood sexual abuse, adolescent violence, or any other experiences in which the patient experiences a strong sense of fear [2,11-13].

In the group of patients diagnosed with DID, the majority have experienced sexual or physical violence, many of them before the age of six [13]. Generally, the principal incidence of dissociative disorders is more common in people with a history of suicide attempts, experience of sexual harassment, and physical or emotional neglect in childhood, as well as in women after an abortion and in patients with other related to gender identification disorders the study by Ross et al. (1990), one hundred and two patients with diagnosed DID estimated that the traumatizing factor usually occurred more than 10 years before the onset of underlying dissociative symptoms [14]. In a group of fifteen patients with DID, compared to 23 mentally healthy patients, a smaller volume of the hippocampus and amygdala was demonstrated, especially in the areas CA2-3, CA4-DG, as well as support "subiculum" (hippocampus) [15], which may be due to chronic exposure of patients with DID to stressors.

The existence of dissociative disorders is also linked to genetic predisposition, which has been suggested by studies of several hundred pairs of monozygotic and dizygotic twins [16]. Attention was paid also to the relationship between the occurrence of DID and the polymorphism of genes related to neurotransmission: the rs 25531 allele of the serotonin transporter gene promoter (5-HTTLPR) [17] and the Val158Met allele catechol-Omethyltransferase [18].

According to the DSM-5 criteria, DID is characterized by the presence of a minimum two separate personalities and the presence of memory gaps. During DID, manifestations can also change in affect, different states 
of consciousness, behavior, perception, and movement and sensation disorders $[2,4]$.

The following are the DID recognition criteria according to DSM-5:

A. Identity interference characterized by two or more distinct personality states that can be described in some cultures as an experience of mastication. Identity disruption is associated with a clear discontinuity in self-sense and willpower, accompanied by related changes in affect, behavior, awareness, memory, perception, cognition, and/ or sensorimotor function. These signs and symptoms may be noticed by others or reported by the patient.

B. Recurring gaps in recalling daily events, important autobiographical information and/or traumatic events that go beyond 'simple forgetfulness'.

C. Symptoms cause significant clinical discomfort or deterioration in social, professional or other important areas.

D. The disorder is not a normal part of widely accepted cultural or religious practice.

E. These symptoms do not arise from the physiological effects of a substance (e.g. loss of consciousness or chaotic behavior during alcohol intoxication) or from another condition (e.g., partial complex seizures) [4, 9].

Separate personality states are usually perceived by both those in the social environment and the patient. It should be noted that the individual personalities are most often unaware of each other's existence, and that patients can experience different identities, including characteristics of gender, age, sexual orientation, and interests (hobbies). Differences in the dominant hemisphere of the brain may occur, which is most often manifested by changes in right- or left-handedness when assuming different identities. In psychiatric, neurological and neuroimaging studies, differences in brain function can be found in relation to the currently dominant personality [4]. Researchers postulate that the patient's original personality remains predominant. In four studies among the more than four hundred patients with DID, there was a median number of identity states between five and ten $[14,19,20]$.

The ICD-10 classification draws attention to the dynamics of the disorder over time. The first personality change in life usually occurs suddenly and is directly related to the action of the stressor involved; subsequent ones are often limited to traumatic events, or occur during therapeutic sessions involving relaxation, hypnosis or a rebound. There are cases of the emergence of a second and subsequent personality during psychotherapy sessions $[2,5,9]$.

\section{CASE DESCRIPTION}

\section{Assessment of mental state by a psychiatrist}

A 30-year-old patient was hospitalized for the first time in his life at the psychiatric ward of the Psychiatric Clinic of the Medical University of Bialystok. He was admitted due to the deterioration of his mental state involving lowered mood, drive, and feelings of anxiety when dealing with people. For the previous 8 years, he had been treated as an outpatient with a diagnosis of paranoid schizophrenia. About 10 years ago, he took hormone therapy to change sex, but interrupted it due to strong fears and outbreaks of aggression. He denied having any chronic diseases, abuse of psychoactive substances, head injuries or epilepsy. No physical deviations were found in the physical and neurological examination.

Mental state: correct auto and allopsychic orientation. Clear awareness, formal contact, withdrawn. The patient spoke about himself in a feminine way. Monotonal expression with rich vocabulary, revealing the features of magical and symbolic thinking. He expressed religious delusions, remained uncritical to the spoken content. He reported a feeling of "unconscious fear" occurring constantly and intensifying in social situations. He denied having hallucinations. He presented features of depersonalization, ambivalence, and ambisententia. He denied his: resignation and suicidal thoughts. He did not report somatic complaints.

During the patient's hospitalization basic tests were performed: morphology, electrolytes, liver tests, glucose, kidney tests and ECG - results all were without deviations from the norm. An MRI of the brain showed no abnormalities. An EEG performed prior to hospitalization showed no abnormalities.

As a result of treatment (antipsychotics - olanzapine $20 \mathrm{mg}$ per day, haloperidol $5 \mathrm{mg}$ per day, and an antidepressant - sertraline $75 \mathrm{mg}$ per day), the patient's mood gradually normalized, sleep quality improved, anxiety subsided. He did not establish social relations spontaneously, presented a schizoid lifestyle, and remained focused on internal experiences. In interpersonal relations he adopted a passive-dependent attitude. In the psychological assessment, he presented himself as an ambitious, erudite person, with a rich vocabulary, an average level of intelligence, a high level of aspiration and life achievement, setting unrealistic goals resulting from disease symptoms.

\section{Description of the patient's mental state based on his conversations with doctor and letters}

The patient reports: "I was born as a boy and I was brought up as a boy, (...) I was a smart, sensitive, curious child, (...) I had no problems with gender identity. (...) My parents did nothing to allow me no way to gain experience in independent living. (...)".

At the age of 10, the patient spent over 2 weeks in a pediatric pneumonia ward, which he describes as: "a stigma on my life", (...), I was so lonely (...), a teenage boy boasted about a knife and threatened me (...), I was a quiet and fearful child (...), other patients teased me, threatened me 
many times. After a week's break, it turned out that I had to go back to the hospital. When I left the walls of the hospital for good, my life returned to normal.

At the age of 12-13, "everything collapsed." "There was a traumatic event whose consequences I certainly feel to this day. A neighbor's dog bit me (...) I felt distrust, I distanced not only from quadrupeds, but also from other species including man".

"As a boy I entered puberty (...) I was already very socially frightened there".

When the patient felt that he was a woman, he wanted to acquire typically female characteristics. The patient was 17 years old when he first thought of attempting to change sex: "in one night my thinking about life changed" (...). The patient felt that he was a woman with the female name, who professed Buddhism. He extensively describes in his letters issues related to the Buddhist religion and his path to Nirvana. At that moment, given the structure of the Polish language, grammatically the patient first began speaking of himself as a female. "I felt I was women (...) I lived, feeling the irrationalism of my psyche, organism, (...) I preferred to run away into the virtual world".

The patient felt that his "psyche disagreed with his body". So he escaped into fantasies about life as a brutal man. At the time, these attracted the patient: he mentions "the army, state dictatorship, wars and conquests of lands"... "When I felt I was a man, I considered in real terms a military career (...), to be a commando; a strong, bold, confident, brutal guy, packed with testosterone".

The patient discontinued his education in the second grade of high school "with a heavy heart".

After some time, he felt in an internal conflict because of the ideology of Nazism: "I came to the conclusion that (...) nowadays, so full of various types of manipulation, we cannot be sure who Hitler really was". When the patient turned 18 he stated for the first time that he was a "totalitarian leader".

At the age of 19, having undergone the necessary examinations, and with the consent of his parents, he began hormone therapy: "I was glad that male traits were weakening, while female ones were progressing". All the time, however, the patient balanced on the border of contradictory life concepts. "I went to see a psychiatrist". "I am going to rebuild what Hitler and other great leaders have seemingly lost".

The patient began to analyze his health and constant changes in the feelings of his condition: "Perhaps I am suffering from or developing a mental illness. I was wondering about schizophrenia (...)". It seemed that the patient had at least partial insight into his mental state at the time. The patient also felt a growing tension as a result of the conflicting feelings in him: "I cannot reconcile three different concepts of life". "If I could decide on one of them (...) or work out a compromise". Yet when he felt the certainty of his path: "internal fear increases", "then
I have a moment of conviction, certainty, I fall into a state of euphoria (...), still my decision turned out to be an illusion again." These "decisions" on personality changes lasted no more than a few days: "It all led me to the decision to commit suicide (...), I changed my mind". "Now she [his female personality author's note] has decided to seek psychiatric help". "I don't know what is true and what is false. I am so lost that I can question everything".

The patient whose case has been presented above has at least three distinct identities. Insight into the presence of other personalities seems to come from a female personality with a female name, which reports on the existence of other identities during the examination and partly describes them in the self-reports given handed to the attending physician (grammatically the patient always speaks of himself as if he were a woman). During the first week of hospitalization the patient presented a coquettish female personality and liked wearing women's clothes. After a week hospitalization, the identity was transformed back into the patient's male basic identity. After a week hospitalization, the identity was transformed back into the patient's male basic identity.

It can be concluded that in addition to the basic male personality, let us call him $\mathrm{X}$, the patient experienced the feeling that he was a woman - Y - and a man, who fantasized about being the totalitarian leader of an army whom we can call Z. In an interview, the patient indicated traumatic experiences during childhood and adolescence. We know from the patient's own account that the change in identity occurred when he felt increasing fear. The patient, from the perspective of a woman with a female name, does not seem to have periods of oblivion. He described these internal changes as an experience of possession. Changes in the sense of identity were accompanied by discontinuity in the sense of self, perception, change of affect, behavior, awareness and perception, both as reported by the patient and described by the family. Symptoms cause clinically significant ailments, and withdrawal from social, school and professional life. The patient negates smoking, drinking alcohol or using drugs. An MRI of the brain with contrast made during hospitalization was normal. Neurological consultation did not show deviations from the norm. The male identity $\mathrm{X}$ is attracted to women, and the female $\mathrm{Y}$ identity to men, which can be deduced from the patient's examination and letters.

The patient was diagnosed with paranoid schizophrenia and the co-occurrent DID. The patient met the diagnostic criteria for both diseases. It seems that through the dissociation mechanism the patient suppresses the negative emotions (anxiety, tension) appearing as a result of exposure to traumatizing factors (resulting from psychotic experiences or difficulties in gender identification).

The patient's condition was analyzed retrospectively on the basis of medical documentation and notes made by him. 


\section{COMMENT}

DID is a multidimensional and chronic dissociative state. The disease is characterized by the presence of two or more separate identity states with a clearly marked discontinuity in a sense of the self linked to the disorders of affect, memory (especially autobiographical), perception, behavior and consciousness. Sensory and movement disorders may also occur in the course of DID. Studies conducted on patients diagnosed with DID indicate the role of environmental and genetic factors in the etiopathogenesis of the disorder. Disturbances of the size of some limbic system structures have also been observed. DID may coexist with other mental and somatic diseases (as evidenced by the case of the patient discussed in this article).

DID is often undiagnosed, and sometimes misdiagnosed. The reason for diagnostic difficulties is the common belief that DID is extremely rare and that there is insufficient knowledge about the disorder. According to the current state of knowledge, the disease seems to be more common than previously thought yet many of its aspects remain unexplored.

Based on medical records, including the attached notes created by the patient as quoted above, we retrospectively analyzed the case of a 30-year-old man who was hospitalized in a psychiatric ward for the first time. The analysis of the documentation indicates that the patient has at least three separate identities, among which the dominant role seemed to be played by the female personality $\mathrm{Y}$, having insight into the existence of the other separate personalities and reporting on the existence of the basic male personality and the male personality of the "totalitarian leader". Probably due to the dominant role of the female personality, the patient began hormone therapy to change sex. The disorders experienced by the patient caused an increased feeling of mental discomfort, deterioration of functioning, and his withdrawal from social life. Due to the interpretation of the patient's statements revealing delusional beliefs, magical and symbolic thinking, ambivalence and ambisententia, he was diagnosed with paranoid schizophrenia with coexistent DID.

So far, no other descriptions have been found in the literature of the of the simultaneous coexistence of these two disorders, which makes the case study presented unique.

Psychiatrists and psychologists, as well as doctors of other specialties should have knowledge about the symptomatology of DID in order to coordinate a holistic diagnostic approach and individualized patient care $[2,21]$.

\section{Conflict of interest/Konflikł interesu}

Absent./Nie występuje.

Financial support/Finansowanie

Absent./Nie występuje.

\section{References/Piśmiennicłwo}

1. Jedlecka W. The notion of "the dissociation" - fundamental issues. Filoz Publiczna i Eduk Demokr 2018; 3: 97-110.

2. Orlof W, Wilczyńska KM, Waszkiewicz N. Dysocjacyjne zaburzenie tożsamości (osobowość mnoga) - powszechniejsze niż wcześniej sądzono. Psychiatria 2018; 15: 228-233.

3. Barton N. Dissociative Identity Disorder. In: Gabbard GO (ed.). Gabbard's Treatments of Psychiatric Disorders. Arlington: American Psychiatric Pub.; 2017.

4. American Psychiatric Association. Diagnostic and Statistical Manual of Mental Disorders, Fifth Edition (DSM-5), Arlington: American Psychiatric Association; 2013. Available at: https://www.sciencetheearth.com/uploads/2/4/ 6/5/24658156/dsm-v-manual_pg490.pdf.

5. Brand BL, Classen CC, McNary SW, Zaveri P. A review of dissociative disorders treatment studies. J Nerv Ment Dis 2009; 197: 646-654.

6. Brand BL, Myrick AC, Ducharme E. Dissociative disorders. In: Grossman LL, Walfish S (eds.). Translating Psychological Research into Practice. New York: Springer Publishing Co.; 2014, pp. 167-173.

7. Ross CA. Epidemiology of multiple personality disorder and dissociation. Psychiatr Clin North Am 1991; 14: 503-517.

8. Sar V, Akyuz G, Dogan O. Prevalence of dissociative disorders among women in the general population. Psychiatry Res 2007; 149: 169-176.

9. Spiegel D, Lewis-Fernández R, Lanius R, Vermetten E, Simeon D, Friedman M. Dissociative disorders in DSM-5. Annu Rev Clin Psychol 2013; 9: 299-326. 
10. Saxe GN, van der Kolk BA, Berkowitz R, Chinman G, Hall K, Lieberg G, Schwartz J. Dissociative disorders in psychiatric inpatients. Am J Psychiatry 1993; 150: 1037-1042.

11. Afifi TO, Mather A, Boman J, Fleisher W, Enns MW, MacMillan H, Sareen J. Childhood adversity and personality disorders: Results from a nationally representative population-based study. J Psychiatr Res 2011; 45: 814-822.

12. Sugaya L, Hasin DS, Olfson M, Lin KH, Grant BF, Blanco C. Child physical abuse and adult mental health: a national study. J Trauma Stress 2012; 25: 384-392.

13. Ellason JW, Ross CA, Fuchs DL. Lifetime axis I and II comorbidity and childhood trauma history in dissociative identity disorder. Psychiatry 1996; 59: 255-266.

14. Ross CA, Miller SD, Reagor P, Bjornson L, Fraser GA, Anderson G. Structured interview data on 102 cases of multiple personality disorder from four centers. Am J Psychiatry 1990; 147: 596-601.

15. Chalavi S, Vissia EM, Giesen ME, Nijenhuis ERS, Draijer N, Cole JH, et al. Abnormal hippocampal morphology in dissociative identity disorder and post-traumatic stress disorder correlates with childhood trauma and dissociative symptoms. Hum Brain Mapp 2015; 36: 1692-1704.

16. Becker-Blease KA, Deater-Deckard K, Eley T, Freyd JJ, Stevenson J, Plomin R. A genetic analysis of individual differences in dissociative behaviors in childhood and adolescence. J Child Psychol Psychiatry Allied Discip 2004; 45: 522-532.

17. Pieper S, Out D, Bakermans-Kranenburg MJ, van Ijzendoorn MH. Behavioral and molecular genetics of dissociation: The role of the serotonin transporter gene promoter polymorphism (5-HTTLPR). J Trauma Stress 2011; 24: 373-380.

18. Savitz JB, Van Der Merwe L, Newman TK, Solms M, Stein DJ, Ramesar RS. The relationship between childhood abuse and dissociation. Is it influenced by catechol-O-methyltransferase (COMT) activity? Int J Neuropsychopharmacol 2008; 11: 149-161.

19. Putnam FW, Guroff JJ, Silberman EK, Barban L, Post RM. The clinical phenomenology of multiple personality disorder: review of 100 recent cases. J Clin Psychiatry 1986; 47: 285-293.

20. Ross CA, Norton GR, Wozney K. Multiple personality disorder: An analysis of 236 cases. Can J Psychiatry 1989; 34: $413-418$.

21. Sar V, Mutluer T, Necef I, Fatih P. Trauma, Creativity, and trance: special ability in a case of dissociative identity disorder. Am J Psychiatry 2018; 175: 506-507. 